Article

\title{
Bovine serum albumin: An efficient and green biocatalyst for the one-pot four-component synthesis of pyrano[2,3-c]pyrazoles
}

\author{
Xingtian Huang a, Zhipeng Li b, Dongyang Wang b, Yiqun Li a,b,* \\ a College of Life Science and Technology, Jinan University, Guangzhou 510632, Guangdong, China \\ b Department of Chemistry, Jinan University, Guangzhou 510632, Guangdong, China
}

\section{A R T I C L E I N F O}

\section{Article history:}

Received 6 March 2016

Accepted 24 March 2016

Published 5 September 2016

\section{Keywords:}

Bovine serum albumin

Biocatalyst

Multicomponent reaction

Pyrano[2,3-c]pyrazole

Biocatalytic promiscuity

\begin{abstract}
A B S T R A C T
The use of biocatalysts is attracting an increasing amount of attention in chemical catalysis. Here, we have shown that bovine serum albumin (BSA), a ubiquitous, inexpensive, non-enzymatic transport protein, can serve as an efficient, retrievable catalyst in the one-pot four-component reaction of aryl aldehydes, malononitrile, hydrazine hydrate, and ethyl acetoacetate for the synthesis of pyrano[2,3-c]pyrazoles under mild reaction conditions. The BSA biocatalyst also displayed a high catalytic affinity for acyclic/cyclic ketones to yield the corresponding pyrano[2,3-c]pyrazoles or their spirocyclic variants. The BSA could be used for at least five cycles without serious loss of catalytic activity. This novel, efficient protocol has the merits of high yield, operational simplicity, and a relatively benign environmental impact. Moreover, the method extends the promiscuity of BSA as a biocatalyst.
\end{abstract}

(C) 2016, Dalian Institute of Chemical Physics, Chinese Academy of Sciences. Published by Elsevier B.V. All rights reserved.

\section{Introduction}

Multicomponent reactions (MCRs) have emerged as powerful and efficient tools for constructing various novel organic molecules of potential interest. These reactions are particularly useful in drug discovery owing to their flexibility and effectiveness compared with conventional multistep synthesis [1-3]. MCRs offer fast and elegant routes to target molecules via one-pot synthetic reaction schemes. These may be either simultaneous reactions or sequential-addition procedures that have high atom economy, bond-forming efficiency, and selectivity. Moreover, MCRs obviate the need for isolation and purification of intermediates, thereby minimizing waste, saving time, and reducing the cost of purification. Pyrano[2,3-c]pyrazoles are an important class of heterocyclic compounds that have been widely explored as they form the essential core of emerging drugs with diverse bioactivity, including a potential inhibitor of human Chk1 kinase [4], as well as antitumor [5], analgesic [6], antibacterial [7], and anti-inflammatory [6-8] agents. Various MCRs, including three-component reactions (3CRs), four-component reactions (4CRs), and even five-component reactions (5CRs), have been reported for the synthesis of pyrano[2,3-c]pyrazole derivatives. 3CRs of carbonyl compounds, malononitrile, and the corresponding pyrazolin-5-ones using various basic catalysts, such as trimethylamine [9], triethanolamine [10], piperidine [11], $\mathrm{N}$-methylmorpholine [12], D/L-proline [13], MgO [14], silica sodium carbonate [15], and electrogenerated bases [16], have been reported. Furthermore, 4CRs have been developed for the reaction of aldehydes, malononitrile, hydrazine hydrate, and ethylacetoacetate using

\footnotetext{
* Corresponding author. Tel/Fax: +86-20-85220223; E-mail: tlyq@jnu.edu.cn

This work was supported by the National Natural Science Foundation of China $(21372099,21072077)$, and the the Natural Science Foundation of Guangdong Province (10151063201000051, 8151063201000016).

DOI: 10.1016/S1872-2067(15)61088-9 | http://www.sciencedirect.com/science/journal/18722067 | Chin. J. Catal., Vol. 37, No. 9, September 2016
} 
trimethylamine [17], Amberlyst A21 [18], cetyltrimethylammonium chloride [19], molecular sieves [20], magnetic $\mathrm{Fe}_{3} \mathrm{O}_{4}$ nanoparticles [21], $\mathrm{SnO}_{2}$ quantum dots [22], L-proline $[23,24]$, glycine [25], meglumine [26], per-6-amino- $\beta$-cyclodextrin [27], and lipase [28] as catalysts. More recently, overall 5CRs have been established involving Suzuki coupling of 4-bromobenzaldehyde and arylboronic acids followed by 4CRs involving readily available ethyl acetoacetate, malononitrile, and hydrazine hydrate [29]. However, in spite of their merits, most of these methods suffer from one or more drawbacks, such as harsh reaction conditions, expensive or unobtainable reagents, stoichiometric amounts of catalyst, long reaction time, unsatisfactory product yields, high waste generation, or laborious work-up. Considering the importance of pyrano[2,3-c]pyrazole derivatives, more convenient and practical methodologies for their synthesis are still needed.

In light of the above, we considered that biocatalysts might be effective for this class of 4CRs owing to their promiscuous activity. Exploiting the ability of a biocatalyst to achieve the synthesis of pyrano[2,3-c]pyrazole derivatives via 4CRs has long been challenging. To date, only one previous study [28], using lipase from Aspergillus niger, has reported the successful use of a biocatalyst for this purpose.

In the past decade, considerable effort has been expended on the development of biocatalysts, including proteins, enzymes, and whole cells, for use in organic synthesis, owing to their high catalytic activity and selectivity, as well as operational simplicity [30,31]. Among them, bovine serum albumin (BSA), a ubiquitous, inexpensive, non-enzymatic transport protein derived from cows, with no natural catalytic function in biological systems, has proven an efficient biocatalyst because of its remarkable versatility for many kinds of catalytic activities and biotransformations [32]. It is capable of binding organic molecules by reversible non-covalent complexation in its hydrophobic pockets, thus providing a microenvironment for a number of organic transformations including reduction [33], Knoevenagel condensation [34,35], aldol condensation [34], nitroaldol addition [36], Gewald reactions [37], Morita-BaylisHillman reactions [38], Biginelli reactions [39], thio-Michael addition [40], oxidative coupling of thiols [41], thiosulfination [42], and oxidation of tertiary amines to N-oxides [43].

Inspired by these results, we tested the use of BSA as a new, efficient and recyclable catalyst for the synthesis of pyrano[2,3-c]pyrazole derivatives via 4CRs (Scheme 1). To the best of our knowledge, there has been no report of the use of BSA as a biocatalyst for 4CRs of this kind to date. Thus, exploiting the promiscuous activity of the abundant and readily available BSA to catalyze MCRs should extend the synthetic utility of biocatalysis.

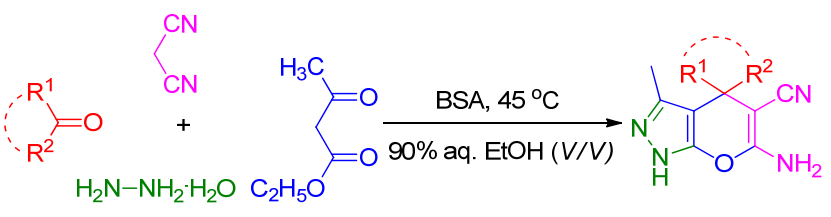

Scheme 1. Synthesis of dihydropyrano[2,3-c]pyrazole.

\section{Experimental}

\subsection{Materials, chemicals, and characterization}

Albumin bovine $\mathrm{V}$ from bovine serum (BSA), hemoglobin from bovine erythrocytes (Lot\# SG201402), egg white albumin, lysozyme from chicken egg (activity $\geq 20000 \mathrm{U} / \mathrm{mg}$, Lot\# KY201501), trypsin from porcine pancreas (activity $\geq 250 \mathrm{U} / \mathrm{g}$, Lot\# KY201305), and lipase from porcine pancreas (activity $\geq$ $30000 \mathrm{U} / \mathrm{g}$, Lot\# KY201312) were purchased from Sigma. Alpha amylase from bacillus submerged fermentation (activity $\geq 3000 \mathrm{U} / \mathrm{g}$, $\mathrm{pH}=5.5-7.5$ ) was purchased from Damao, and silk fibroin was extracted from silk by a previously reported method [44]. All chemicals were obtained from commercial sources and used as received.

Fourier transform infrared (FT-IR) spectra were recorded on a Nicolet 6700 spectrometer in $\mathrm{KBr}$ pellets in the range 4000-400 $\mathrm{cm}^{-1}$. ${ }^{1} \mathrm{H}$ NMR (300 MHz) and ${ }^{13} \mathrm{C}$ NMR (75 MHz) spectra were obtained on a Bruker AC-300 using DMSO- $d_{6}$ as the solvent and TMS as the internal standard. The melting points were measured on an Electrothermal X6 microscopic digital melting point apparatus.

\subsection{Typical biocatalytic procedure for synthesis of pyrano[2,3-c]pyrazoles}

A round-bottomed flask was charged with ethyl acetoacetate $(1 \mathrm{mmol}), 80 \%$ hydrazine hydrate $(V / V, 1 \mathrm{mmol})$, malononitrile ( $1 \mathrm{mmol})$, the chosen carbonyl compound (1 mmol), BSA ( $50 \mathrm{mg}$ ), and $5 \mathrm{~mL} 90 \%$ aqueous ethanol solution $(V / V)$. The reaction was incubated at $45^{\circ} \mathrm{C}$ and stirred at 500 $\mathrm{r} / \mathrm{min}$ for a specific time until completion. The progress was tracked by thin-layer chromatography. Upon completion, ethyl acetate preheated to $60{ }^{\circ} \mathrm{C}$ was added to quench the reaction. The BSA was recovered by filtration, washed adequately with ethanol and dried in preparation for the next run. The organic fraction was successively washed with brine and saturated sodium bisulfite solution and then concentrated on a rotary evaporator to give the crude product. The product was further purified by recrystallization with ethanol. The target products were identified by FT-IR, ${ }^{1} \mathrm{H}$ NMR, ${ }^{13} \mathrm{C}$ NMR, and melting point, all of which were in agreement with the literature values.

\section{Results and discussion}

\subsection{Screening of different biocatalysts}

Initially, various biocatalysts, including enzymes and proteins, were screened using the 4CR of ethyl acetoacetate, hydrazine hydrate, malononitrile, and $p$-chlorobenzaldehyde as a model reaction. The results are summarized in Table 1. Among all the screened biocatalysts, BSA showed the most powerful catalytic activity, achieving a rapid reaction time of $0.75 \mathrm{~h}$ and affording the desired product in 95\% yield (Table 1, entry 9). The use of other enzymes or proteins also resulted in appreciably greater yields (Table 1, entries 2-8). The lowest product yield was obtained in the absence of any catalyst (Table 1 , entry 
Table 1

Screening of biocatalysts.

\begin{tabular}{lccc}
\hline \multirow{2}{*}{ Entry } & Biocatalyst & \multicolumn{2}{c}{ Time Yield $^{\mathrm{a}}$} \\
& (h) & (\%) \\
\hline 1 & None & 6 & 47 \\
2 & Lysozyme from chicken egg & 6 & 63 \\
3 & Alpha amylase from bacillus submerged fermentation & 3 & 75 \\
4 & Hemoglobin from bovine erythrocytes & 3 & 82 \\
5 & Silk fibroin & 3 & 84 \\
6 & Trypsin from porcine pancreas & 3 & 86 \\
7 & Egg white albumin & 2 & 86 \\
8 & Lipase from porcine pancreas & 1 & 85 \\
9 & BSA & 0.75 & 95 \\
\hline
\end{tabular}

Reaction conditions: 4-chlorobenzaldehyde (1 mmol), malononitrile (1 mmol), hydrazine hydrate $(1 \mathrm{mmol})$, ethyl acetoacetate $(1 \mathrm{mmol})$ and biocatalyst (50 mg) in EtOH/water $(9: 1 \mathrm{~V} / \mathrm{V}, 5 \mathrm{~mL})$ at $45^{\circ} \mathrm{C}$.

a Isolated yield.

1), showing that catalysis plays a key role in this transformation. Encouraged by this result, we proceeded to explore in detail the influence of the catalyst dose, reaction medium, and reaction temperature on the model reaction using catalytic amounts of BSA.

\subsection{Optimization of reaction conditions}

The dosage of the biocatalyst was found to have an appreciable effect on the product yields. The 4CR model was studied with catalyst doses ranging from 0.0 to $60.0 \mathrm{mg}$ of the substrate (Table 2). The 4CR model was found to proceed efficiently even with a low dose of BSA (15 mg in substrate), affording an $80 \%$ product yield (Table 2, entry 2). As can be seen from Table 2, with the catalyst dose increased from 15 to $50 \mathrm{mg}$, the apparent yield increased from $80 \%$ to $95 \%$ and the reaction time decreased from 1.5 to $0.75 \mathrm{~h}$ (Table 2, entries $2-5)$. Further increasing the catalyst dose to 55 or even $60 \mathrm{mg}$ had no major effect on the product yield (Table 2, entries 6 and 7). Recall that, in the absence of BSA, the model reaction proceeded with a prolonged reaction time and a lower yield (Table 2, entry 1). In contrast, $50 \mathrm{mg}$ of BSA biocatalyst was sufficient to drive the reaction to completion in short time.

The reaction medium generally plays an important role in biocatalysis. To identify the most suitable solvent, ten protic and aprotic solvents with varying polarities or other properties were screened. Several protic solvents, including EtOH, aqueous $\mathrm{EtOH}$, and $\mathrm{MeOH}$, rendered high product yields (Table 2, entries 2-15), while in aprotic solvents, including $\mathrm{CH}_{2} \mathrm{Cl}_{2}$, $\mathrm{CH}_{3} \mathrm{CN}, \mathrm{DMF}$, and DMSO, BSA exhibited low catalytic activity (Table 2, entries 18-21). Poor yields were also obtained in $\mathrm{H}_{2} \mathrm{O}$, $i$-PrOH, and the absence of solvent (Table 2, entries 16-17 and 22). Based on the screening results, $90 \% \mathrm{EtOH}(V / V)$ was chosen as the most suitable solvent for further study.

Reaction temperature is an important parameter in biocatalysis. To further investigate the optimum conditions for the model MCR, we evaluated the effect of six different temperatures in the range $25-78{ }^{\circ} \mathrm{C}$ on the reaction yield and reaction time. Both these variables were found to be highly sensitive to temperature. As shown in Table 2, the product
Table 2

Optimization of reaction conditions.

\begin{tabular}{|c|c|c|c|c|c|}
\hline Entry & Solvent & $\begin{array}{c}\text { Catalyst } \\
\text { (mg) }\end{array}$ & $\begin{array}{c}\text { Temp. } \\
\left({ }^{\circ} \mathrm{C}\right)\end{array}$ & $\begin{array}{c}\text { Time } \\
\text { (h) }\end{array}$ & $\begin{array}{c}\text { Yield }^{a} \\
(\%)\end{array}$ \\
\hline 1 & $90 \% \mathrm{EtOH}(\mathrm{V} / \mathrm{V})$ & 0 & 45 & 6.0 & 47 \\
\hline 2 & $90 \%$ EtOH $(V / V)$ & 15 & 45 & 1.5 & 80 \\
\hline 3 & $90 \%$ EtOH $(V / V)$ & 30 & 45 & 1.0 & 87 \\
\hline 4 & $90 \%$ EtOH $(V / V)$ & 45 & 45 & 0.75 & 91 \\
\hline 5 & $90 \%$ EtOH $(V / V)$ & 50 & 45 & 0.75 & 95 \\
\hline 6 & $90 \% \mathrm{EtOH}(\mathrm{V} / \mathrm{V})$ & 55 & 45 & 0.75 & 93 \\
\hline 7 & $90 \%$ EtOH $(V / V)$ & 60 & 45 & 0.75 & 93 \\
\hline 8 & $95 \%$ EtOH $(V / V)$ & 50 & 25 & 2.0 & 85 \\
\hline 9 & $95 \% \mathrm{EtOH}(V / V)$ & 50 & 35 & 1.5 & 88 \\
\hline 10 & $95 \%$ EtOH $(V / V)$ & 50 & 55 & 0.5 & 87 \\
\hline 11 & $95 \%$ EtOH $(V / V)$ & 50 & 65 & 0.4 & 88 \\
\hline 12 & $95 \%$ EtOH $(V / V)$ & 50 & 75 & 0.25 & 88 \\
\hline 13 & EtOH & 50 & 45 & 0.75 & 88 \\
\hline 14 & $75 \%$ EtOH $(V / V)$ & 50 & 45 & 0.75 & 86 \\
\hline 15 & $\mathrm{MeOH}$ & 50 & 45 & 1.0 & 84 \\
\hline 16 & $i$-PrOH & 50 & 45 & 1.5 & 35 \\
\hline 17 & $\mathrm{H}_{2} \mathrm{O}$ & 50 & 45 & 3.0 & 38 \\
\hline 18 & $\mathrm{CH}_{2} \mathrm{Cl}_{2}$ & 50 & 45 & 1.0 & 55 \\
\hline 19 & $\mathrm{CH}_{3} \mathrm{CN}$ & 50 & 45 & 1.0 & 42 \\
\hline 20 & DMF & 50 & 45 & 1.5 & 63 \\
\hline 21 & DMSO & 50 & 45 & 1.5 & 58 \\
\hline 22 & None & 50 & 45 & 3.0 & 15 \\
\hline
\end{tabular}

Reaction conditions: 4-chlorobenzaldehyde (1 mmol), malononitrile (1 mmol), hydrazine hydrate ( $1 \mathrm{mmol})$, and ethyl acetoacetate $(1 \mathrm{mmol})$ were stirred in the presence of BSA in the solvent $(5 \mathrm{~mL})$ at $45^{\circ} \mathrm{C}$. asolated yield.

yield increased from $85 \%$ to $95 \%$ and the reaction time decreased from 2 to $0.75 \mathrm{~h}$ when the temperature was raised from $25{ }^{\circ} \mathrm{C}$ (room temperature) to $45^{\circ} \mathrm{C}$ (Table 2, entries 8, 9 and 5). However, temperatures over $45{ }^{\circ} \mathrm{C}$ led to lower yields (Table 2, entries 10-12), possibly because of the partial deactivation of the biomolecular BSA at these temperatures, indicating the importance of an appropriate operating temperature to retain biocatalytic activity. Therefore, $45^{\circ} \mathrm{C}$ was selected as the optimal temperature for the reaction.

\subsection{Synthesis of pyrano[2,3-c]pyrazoles}

To obtain further insight into the catalytic possibilities of BSA, we investigated the scope and generality of the 4CRs for which it displays activity. A variety of substituted aryl aldehydes carrying either electron-withdrawing or electron-donating substituents on the aromatic ring were reacted with malononitrile, hydrazine hydrate, and ethyl acetoacetate in $90 \%$ aqueous ethanol in the presence of catalytic amounts of BSA under the above-mentioned optimal conditions. As shown in Table 3, all of the reactions proceeded smoothly to produce the expected pyrano[2,3-c]pyrazoles with excellent yields of 73\%-96\%. With both electron-donating and electron-withdrawing substituents, at either the para or the meta position on the aromatic ring of the aryl aldehyde, the reactions proceeded without marked effects on their progress and with high yields. Notably, the reactions of the aryl aldehydes bearing a substituent at the ortho position afforded slightly lower yields owing to 
Table 3

Synthesis of pyrano[2,3-c]pyrazoles.

\begin{tabular}{|c|c|c|c|c|c|c|c|c|c|c|c|}
\hline Entry & $\begin{array}{c}\text { Carbonyl } \\
\text { compound }\end{array}$ & Product & $\begin{array}{c}\text { Time } \\
\text { (h) }\end{array}$ & $\begin{array}{l}\text { Yield }^{a} \\
(\%)\end{array}$ & M.P. ${ }^{\mathrm{b}}\left({ }^{\circ} \mathrm{C}\right)$ & Entry & $\begin{array}{c}\text { Carbonyl } \\
\text { compound }\end{array}$ & Product & $\begin{array}{c}\text { Time } \\
(\mathrm{h})\end{array}$ & $\begin{array}{c}\text { Yield }^{a} \\
(\%)\end{array}$ & M.P. ${ }^{b}\left({ }^{\circ} \mathrm{C}\right)$ \\
\hline 1 & & & 0.75 & 95 & $\begin{array}{c}232-234 \\
(233-234[45])\end{array}$ & 12 & & & 0.75 & 91 & $\begin{array}{c}220-221 \\
(223-224[48])\end{array}$ \\
\hline 2 & & & 1.5 & 87 & $\begin{array}{c}242-243 \\
(245-246[26])\end{array}$ & 13 & & & 0.75 & 95 & $\begin{array}{c}244-246 \\
(245-246[48])\end{array}$ \\
\hline 3 & & & 1 & 90 & $\begin{array}{c}222-223 \\
(229-230[26])\end{array}$ & 14 & & & 0.75 & 89 & $\begin{array}{c}233-235 \\
(233-234[48])\end{array}$ \\
\hline 4 & & & 0.75 & 91 & $\begin{array}{c}179-180 \\
(178-180[46])\end{array}$ & 15 & & & 0.75 & 88 & $\begin{array}{c}168-170 \\
(167-169[46])\end{array}$ \\
\hline 5 & & & 2 & 84 & $\begin{array}{c}259-261 \\
(259-261[47])\end{array}$ & 16 & & & 6 & 85 & $\begin{array}{c}175-177 \\
(175[49])\end{array}$ \\
\hline 6 & & & 1.5 & 86 & $\begin{array}{c}221-223 \\
(223-224[48])\end{array}$ & 17 & & & 8 & 73 & $173-175$ \\
\hline 7 & & & 0.5 & 96 & $\begin{array}{c}249-251 \\
(249-250[28])\end{array}$ & 18 & & & 12 & 75 & $\begin{array}{c}176-178 \\
(177-178[18])\end{array}$ \\
\hline 8 & & & 1 & 90 & $\begin{array}{c}221-223 \\
(220-222[46])\end{array}$ & 19 & & & 3 & 89 & $\begin{array}{c}245-246 \\
(244-247[7])\end{array}$ \\
\hline 9 & & & 0.75 & 92 & $\begin{array}{c}195-196 \\
(193-195[46])\end{array}$ & 20 & & & 3 & 90 & $\begin{array}{c}289-290 \\
(286-287[26])\end{array}$ \\
\hline 10 & & & 0.75 & 94 & $\begin{array}{c}204-205 \\
(206-208[46])\end{array}$ & 21 & & & 3 & 88 & $\begin{array}{c}247-248 \\
(245-246[26])\end{array}$ \\
\hline 11 & & & 0.75 & 90 & $\begin{array}{c}212-214 \\
(212-213[48])\end{array}$ & $22^{c}$ & & & 1 & 95 & $\begin{array}{c}>300 \\
(300[50])\end{array}$ \\
\hline
\end{tabular}

Reaction conditions: carbonyl compound $(1 \mathrm{mmol})$, hydrazine hydrate $(1 \mathrm{mmol})$, malononitrile $(1 \mathrm{mmol})$, and ethyl acetoacetate $(1 \mathrm{mmol})$ were stirred in the presence of BSA $(50 \mathrm{mg})$ in $90 \% \mathrm{EtOH} /$ water $(\mathrm{V} / \mathrm{V}, 5 \mathrm{~mL})$ at $45^{\circ} \mathrm{C}$.

a Isolated yield.

${ }^{\mathrm{b}}$ The data in parentheses are the melting points reported in the literature.

cTwo equivalents of hydrazine hydrate, malononitrile, and ethyl acetoacetate were used. 
the steric effect (Table 3, entries 2, 3, 5, and 8). Many sensitive functional groups were compatible with the BSA biocatalyst, such as methoxy, phenolic hydroxy, and $N, N$-dimethylamino, and gave high yields (Table 3 , entries 11, 12, 14, and 15). Apart from the aryl aldehydes, various ketones were also used as components in the 4CR scheme, under similar conditions, to produce the desired pyrano[2,3-c]pyrazole derivatives in excellent yields with slightly prolonged reaction time (Table 3, entries 16-21). All of the products were fully characterized by melting point and FT-IR, ${ }^{1} \mathrm{H}$ NMR, and ${ }^{13} \mathrm{C}$ NMR spectroscopy.

\subsection{Catalyst reusability}

For practical application, the reusability of a catalyst is a crucial factor. To explore this aspect of BSA, catalytic recycling experiments were performed using the 4CR of 4-chlorobenzaldehyde, hydrazine hydrate, malononitrile and ethyl acetoacetate as a model reaction. After completing the reaction, the BSA could be conveniently and efficiently recovered from the reaction mixture by filtering, washing successively with acetone three times, and then drying. The recovered BSA was then reused directly in consecutive cycles of the reaction under the above mentioned optimized conditions. The results (Fig. 1) show that only a slight loss of the catalytic activity of BSA was observed after each cycle.

\subsection{Proposed mechanism for synthesis of pyrano[2,3-c]pyrazoles}

The protein BSA has no known natural catalytic function. Structurally, BSA contains 60 Lys, 41 Asp and 58 Glu residues [51] and, with an isoelectric point near $\mathrm{pH}=4.5$ [52], presents as mildly basic at neutral pH. The catalytic activity of BSA is determined by the basic character of the amino groups on the side chains of certain residues, especially lysine. Therefore, we propose the following mechanism for the synthesis of pyrano[2,3-c]pyrazoles via a tandem process, as depicted in Scheme 2. First, an $-\mathrm{NH}_{2}$ group on BSA simultaneously promotes both the condensation of ethyl acetoacetate with hydrazine hydrate and the Knoevenagel condensation of the aryl aldehyde with malononitrile to produce the 3-methyl1H-pyrazol-5(4H)-one $\mathbf{A}$ and the intermediate olefin $\mathbf{B}$. Subsequent Michael addition of $\mathbf{A}$ and $\mathbf{B}$ promoted by $-\mathrm{NH}_{2}$ on BSA produces the intermediate $\mathbf{C}$. Finally, we propose that $\mathbf{C}$ undergoes intramolecular cyclization followed by tautomerization to give the dihydropyrano[2,3-c]pyrazole derivatives.

\section{Conclusions}

We have developed a novel, efficient, and environmentally friendly protocol for the synthesis of a diverse range of pyrano[2,3-c]pyrazole derivatives using BSA as a reusable biocatalyst. This method offers the advantages of environmental compatibility, mild reaction conditions, short reaction time, high yields and operational simplicity. Moreover, the method is distinguished by its multicomponent process and wide substrate scope, accepting a variety of carbonyl compounds as starting

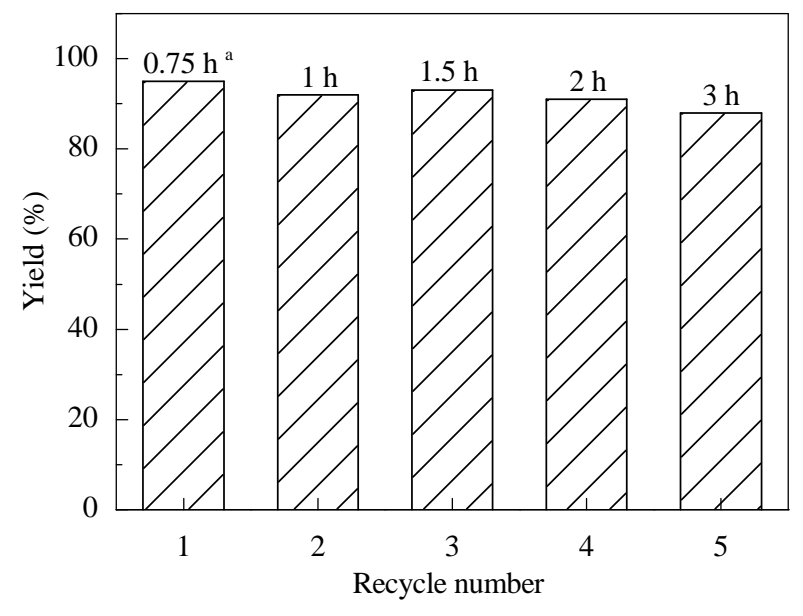

Fig. 1. Recyclability of BSA. ${ }^{\text {a }}$ Reaction time.

materials, which make it a useful and practical process for the synthesis of structurally diverse pyrano[2,3-c]pyrazole derivatives.

\section{References}

[1] Y. L. Gu, Green Chem., 2012, 14, 2091-2128.

[2] B. B. Touré, D. G. Hall, Chem. Rev., 2009, 109, 4439-4486.

[3] A. Dömling, Chem. Rev., 2006, 106, 17-89.

[4] N. Foloppe, L. M. Fisher, R. Howes, A. Potter, A. G. S. Robertson, A. E. Surgenor, Bioorg. Med. Chem., 2006, 14, 4792-4802.

[5] J. L. Wang, D. X. Liu, Z. J. Zhang, S. M. Shan, X. B. Han, S. M. Srinivasula, C. M. Croce, E. S. Alnemri, Z. W. Huang, Proc. Natl. Acad. Sci. U. S. A., 2000, 97, 7124-7129.

[6] S. C. Kuo, L. J. Huang, H. Nakamura, J. Med. Chem., 1984, 27, 539-544.

[7] S. R. Mandha, S. Siliveri, M. Alla, V. R. Bommena, M. R. Bommineni, S. Balasubramanian, Bioorg. Med. Chem. Lett., 2012, 22, 5272-5278.

[8] M. E. A. Zaki, H. A. Soliman, 0. A. Hiekal, A. E. Rashad, Z. Naturforsch C, 2006, 61, 1-5.

[9] A. M. Shestopalov, Y. M. Emeliyanova, A. A. Shestopalov, L. A. Rodinovskaya, Z. I. Niazimbetova, D. H. Evans, Tetrahedron, 2003, 59, 7491-7496.

[10] R. Gr. Redkin, L. A. Shemchuk, V. P. Chernykh, O. V. Shishkin, S. V. Shishkina, Tetrahedron, 2007, 63, 11444-11450.

[11] H. G. Kathrotiya, R. G. Patel, M. P. Patel, J. Serb. Chem. Soc., 2012, 77, 983-991.

[12] F. Lehmann, M. Holm, S. Laufer, J. Comb. Chem., 2008, 10, 364-367.

[13] S. B. Guo, S. X. Wang, J. T. Li, Synth. Commun., 2007, 37, 2111-2120.

[14] H. Sheibani, M. Babaie, Synth. Commun., 2010, 40, 257-265.

[15] K. Eskandari, B. Karami, S. Khodabakhshi, Catal. Commun., 2014, 54, 124-130.

[16] A. M. Shestopalov, Y. M. Emeliyanova, A. A. Shestopalov, L. A. Rodinovskaya, Z. I. Niazimbetova, D. H. Evans, Org. Lett., 2002, 4, 423-425.

[17] Y. M. Litvinov, A. A. Shestopalov, L. A. Rodinovskaya, A. M. Shestopalov, J. Comb. Chem., 2009, 11, 914-919.

[18] M. Bihani, P. P. Bora, G. Bez, H. Askari, ACS Sustain. Chem. Eng., 2013, 1, 440-447.

[19] M. S. Wu, Q. Q. Feng, D. H. Wan, J. Y. Ma, Synth. Commun., 2013, 43, 


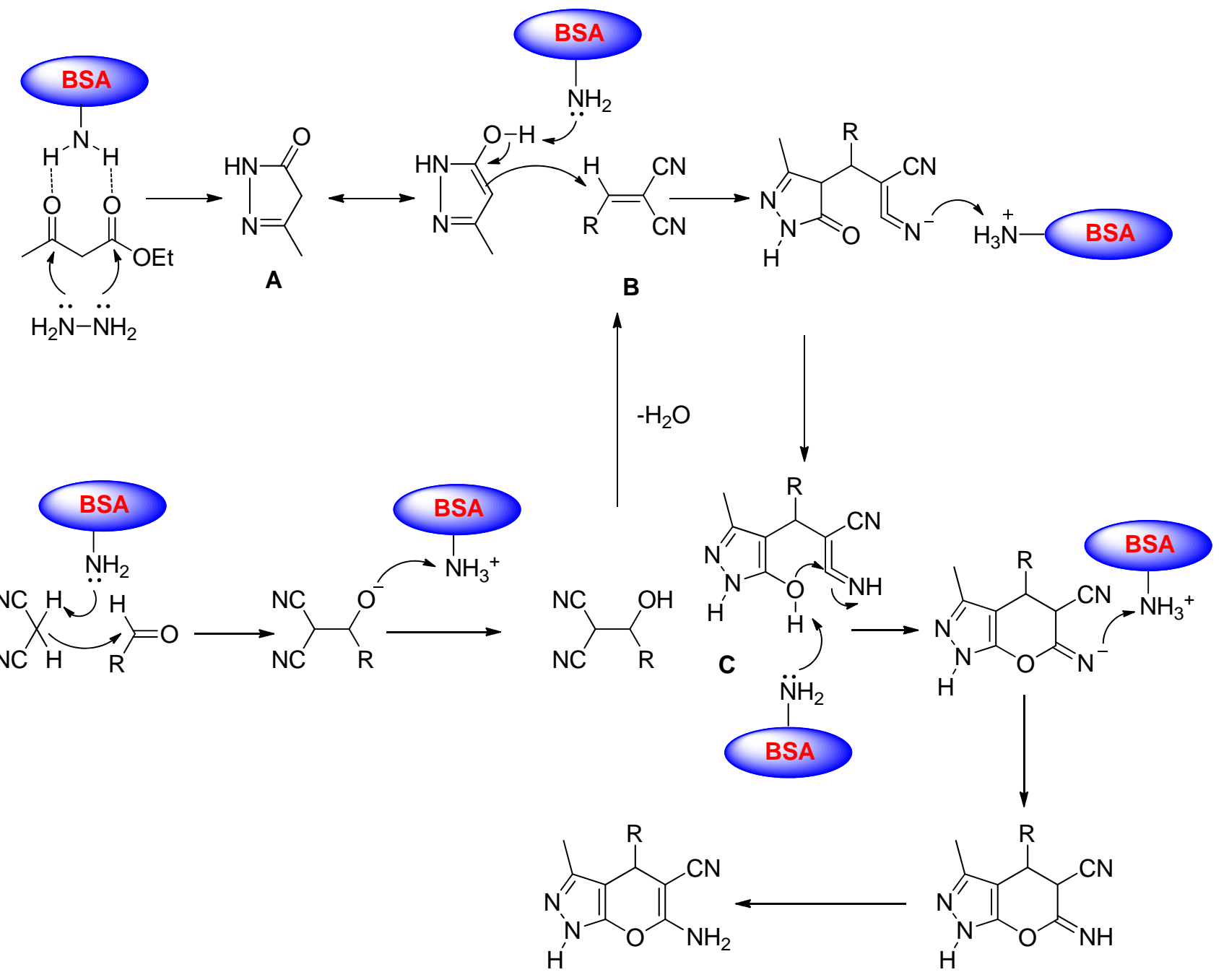

Scheme 2. Proposed mechanism for synthesis of pyrano[2,3-c]pyrazoles.

1721-1726.

[20] J. B. Gujar, M. A. Chaudhari, D. S. Kawade, M. S. Shingare, Tetrahedron Lett., 2014, 55, 6030-6033.

[21] M. A. E. A. A. A. El-Remaily, Tetrahedron, 2014, 70, 2971-2975.

[22] S. Paul, K. Pradhan, S. Ghosh, S. K. De, A. R. Das, Tetrahedron, 2014, 70, 6088-6099.

[23] J. M. Khurana, B. Nand, S. Kumar, Synth. Commun., 2011, 41, 405-410.

[24] H. Mecadon, Md. R. Rohman, I. Kharbangar, B. M. Laloo, I. Kharkongor, M. Rajbangshi, B. Myrboh, Tetrahedron Lett., 2011, 52, 3228-3231.

[25] M. B. M. Reddy, V. P. Jayashankara, M. A. Pasha, Synth. Commun., 2010, 40, 2930-2934.

[26] R. Y. Guo, Z. M. An, L. P. Mo, S. T. Yang, H. X. Liu, S. X. Wang, Z. H. Zhang, Tetrahedron, 2013, 69, 9931-9938.

[27] K. Kanagaraj, K. Pitchumani, Tetrahedron Lett., 2010, 51, 3312-3316.

[28] P. P. Bora, M. Bihani, G. Bez, J. Mol. Catal. B, 2013, 92, 24-33.

[29] Z. X. Lu, J. L. Xiao, D. Y. Wang, Y. Q. Li, Asian J. Org. Chem., 2015, 4, 487-492.

[30] U. T. Bornscheuer, R. J. Kazlauskas, Angew. Chem. Int. Ed., 2004, 43, 6032-6040.

[31] J. M. Woodley, Trends Biotechnol., 2008, 26, 321-327.
[32] S. V. Dzyuba, A. M. Klibanov, Tetrahedron: Asymmetry, 2004, 15, 2771-2777.

[33] F. Benedetti, F. Berti, I. Donati, M. Fregonese, Chem. Commun., 2002, 828-829.

[34] N. Sharma, U. K. Sharma, R. Kumar, N. Katoch, R. Kumar, A. K. Sinha, Adv. Synth. Catal., 2011, 353, 871-878.

[35] P. Ramesh, B. Shalini, N. W. Fadnavis, RSC Adv., 2014, 4, 7368-7373.

[36] E. Busto, V. Gotor-Fernández, V. Gotor, Org. Process Res. Dev., 2011, 15, 236-240.

[37] D. D. Zhao, L. Li, F. Xu, Q. Wu, X. F. Lin, J. Mol. Catal. B, 2013, 95, 29-35.

[38] M. T. Reetz, R. Mondière, J. D. Carballeira, Tetrahedron Lett., 2007, 48, 1679-1681.

[39] U. K. Sharma, N. Sharma, R. Kumar, A. K. Sinha, Amino Acids, 2013 44, 1031-1037.

[40] N. Gaggero, D. C. M. Albanese, G. Celentano, S. Banfi, A. Aresi, Tetrahedron: Asymmetry, 2011, 22, 1231-1233.

[41] Saima, A. G. Lavekar, R. Kumar, A. K. Sinha, J. Mol. Catal. B, 2015, 116, 113-123.

[42] S. V. Dzyuba, A. M. Klibanov, Biotechnol. Lett., 2003, 25, 19611965.

[43] S. Colonna, N. Gaggero, J. Drabowicz, P. Lyzwa, M. Mikolajczyk, 


\title{
Graphical Abstract
}

Chin. J. Catal., 2016, 37: 1461-1468 doi: 10.1016/S1872-2067(15)61088-9

Bovine serum albumin: An efficient and green biocatalyst for the one-pot four-component synthesis of pyrano[2,3-c]pyrazoles

Xingtian Huang, Zhipeng Li, Dongyang Wang, Yiqun Li* Jinan University

Bovine serum albumin has been used as an efficient and reusable biocatalyst for the synthesis of pyrano[2,3-c]pyrazoles under mild and environmentally benign conditions.

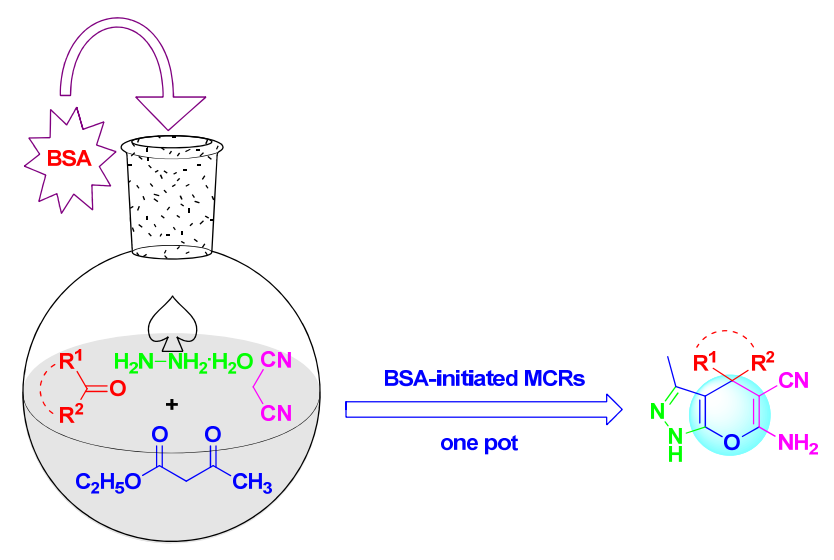

Chem. Commun., 1999, 1787-1788.

[44] B. B. Pekșen, C. Üzelakçil, A. Güneș, Ö. Malay, O. Bayraktar, J. Chem. Technol. Biotechnol., 2006, 81, 1218-1224.

[45] J. M. Khurana, A. Chaudhary, Green Chem. Lett. Rev., 2012, 5, 633-638.

[46] H. Mecadon, Md. R. Rohman, M. Rajbangshi, B. Myrboh, Tetrahedron Lett., 2011, 52, 2523-2525.

[47] A. R. Moosavi-Zare, M. A. Zolfigol, E. Noroozizadeh, M. Tavasoli, V. Khakyzadeh, A. Zare, New J. Chem., 2013, 37, 4089-4094.
[48] Y. Q. Peng, G. H. Song, R. L. Dou, Green Chem., 2006, 8, 573-575.

[49] H. M. Al-Matar, K. D. Khalil, A. Y. Adam, M. H. Elnagdi, Molecules, 2010, 15, 6619-6629.

[50] K. Ablajan, L. J. Wang, Z. Maimaiti, Y. T. Lu, Monatsh. Chem., 2014, 145, 491-496.

[51] K. Hirayama, S. Akashi, M. Furuya, K. Fukuhara, Biochem. Biophys. Res. Commun., 1990, 173, 639-646.

[52] C. Tanford, S. A. Swanson, W. S. Shore, J. Am. Chem. Soc., 1955, 77, 6414-6421.

\section{牛血清白蛋白: 一种催化四组分反应合成吡喃[2,3-c]并吡唑类化合物 的高效和绿色生物催化剂}

\author{
黄杏甜 ${ }^{\mathrm{a}}$, 李志鹏 ${ }^{\mathrm{b}}$, 王东阳 ${ }^{\mathrm{b}}$, 李毅群 $\mathrm{a}, \mathrm{b},{ }^{*}$ \\ 暨南大学生命科学技术学院, 广东广州 510632 \\ 櫭南大学化学系, 广东广州 510632
}

摘要: 多组分反应 (MCRs) 是通过一锅法同时或先后加入 3 种或 3 种以上起始原料合成目标产物的过程, 具有原子经济性 高、化学键构造效率高和反应选择性高等优点, 而且可以避免中间体分离和纯化, 从而减少废物产生, 节省时间, 简化分离 纯化过程. MCRs 由于其灵活性和高效性超过了传统多步合成方法, 已成为构建结构新颖的多样性有机分子的新兴工具, 尤其是在新药开发中具有广泛应用.

吡喃[2,3-c]并吡唑是一类重要杂环化合物, 是许多重要新兴药物的关键内核, 这些药物具有抑制人类 Chk1 激酶活性、 抗肿瘤活性、止痛镇痛活性、抗菌活性和抗炎活性等. 目前已有通过三组分反应 (3CRs)、四组分反应 (4CRs)乃至五组分 反应 (5CRs) 合成吡喃[2,3-c]并吡唑的文献报道. 所用催化剂大多为无机或有机碱性催化剂, 所报道的多组分反应或多或 少存在一些不足, 如反应条件苛刻、所使用试剂昂贵和不易获得、使用定量的催化剂、产率不理想及操作繁琐等.

牛血清白蛋白 (BSA) 是一种来源于牛, 在生物体系中没有天然催化功能的廉价易得的非酶转运蛋白. 由于生物催化剂 如蛋白质、酶及完整细胞等具有催化效率高、选择性高和操作简单等优点, 将生物催化剂用于催化有机反应已成为化学领 域的研究热点. 在这些生物催化剂中, BSA 能催化一系列有机反应, 包括还原反应、Knoevenagel 缩合、 aldol 缩合、 Morita-Baylis-Hillman 反应和Biginelli 反应等.

考虑到吡喃[2,3-c]并吡唑衍生物的重要性以及 BSA 催化有机反应的多样性, 我们设想利用生物催化剂 BSA 催化 $4 \mathrm{CRs}$ 合成吡喃 $[2,3-\mathrm{C}]$ 并吡唑衍生物, 即在 $45^{\circ} \mathrm{C}$ 下, 于 $90 \%$ 乙醇水溶液中, 催化量 BSA 催化乙酰乙酸乙酯、水合肼、丙二 腈和羰基化合物反应. 反应完成后, 产物经乙醇重结晶纯化, BSA 可回收重复使用, 重复使用 5 次, 催化活性基本保持不变. 在优化条件下, 合成了 22 个吡喃[2,3-c]并吡唑衍生物或及其螺环衍生物. 迄今为止, 该法尚未见文献报道. 
总之, 我们发展了一种新颖和有效的 BSA 催化构建结构多样性吡喃[2,3-c]并吡唑衍生物的绿色方法. 该法具有环境友 好、反应条件温和、反应时间短、产率高和操作简单等优点. 同时, 该法底物适应范围广, 可以使用各种羰基化合物为起 始原料, 这使它成为一种高效实用的合成结构多样性吡喃[2,3-c]并吡唑衍生物的方法.

关键词: 牛血清白蛋白; 生物催化剂; 多组分反应; 吡喃[2,3-c]并吡唑; 生物催化多样性

收稿日期: 2016-03-06. 接受日期: 2016-03-24. 出版日期: 2016-09-05.

*通讯联系人. 电话/传真: (020)85220223; 电子信箱: tlyq@jnu.edu.cn

基金来源：国家自然科学基金 (21372099, 21072077); 广东省自然科学基金 (10151063201000051, 8151063201000016).

本文的英文电子版由Elsevier出版社在ScienceDirect上出版(http://www.sciencedirect.com/science/journal/18722067). 